\title{
Knowledge and attitudes of nurses towards alcohol and related problems: the impact of an educational intervention*
}

\author{
ATITUDES E CONHECIMENTOS DE ENFERMEIROS FRENTE AO ÁLCOOL E \\ PROBLEMAS ASSOCIADOS: IMPACTO DE UMA INTERVENÇÃO EDUCATIVA \\ CONOCIMIENTOS Y ACTITUDES DE LAS ENFERMERAS SOBRE EL ALCOHOL Y LOS \\ PROBLEMAS ASOCIADOS: IMPACTO DE UNA INTERVENCIÓN EDUCATIVA
}

\section{Janaina Soares ${ }^{1}$, Divane de Vargas ${ }^{2}$, Maria Lucia Oliveira de Souza Formigoni ${ }^{3}$}

\begin{abstract}
An exploratory study of quasi-experimental approach that aimed to verify the impact of an educational intervention on attitudes and knowledge of nurses towards alcohol use and associated problems. The sample included 185 nurses, divided into two groups: 84 submitted to a training course and formed the experimental group. Data were collected through a knowledge survey and an attitude scale. The attitudes of the participants of both groups were positive. There were no significant differences between groups in relation to knowledge. The strongest predictors of positive attitudes were possessed preparation to act with chemical dependents $(\mathrm{OR}=2.18)$, have received increased workload during graduation on the theme, alcohol and other drugs $(\mathrm{OR}=1.70)$, and completed graduate school $(O R=2.59)$. The educational intervention had a positive impact on the attitudes of nurses towards alcoholics, work and interpersonal relationships with such clientele.
\end{abstract}

\section{DESCRIPTORS}

Education, nursing

Alcoholism

Health knowledge, attitudes, practice

Public health nursing

\section{RESUMO}

Estudo exploratório de abordagem quase experimental que objetivou verificar o impacto de uma intervenção educativa em atitudes e conhecimentos de enfermeiros frente ao uso de álcool e problemas associados. A amostra incluiu 185 enfermeiros, divididos em dois grupos: 84 foram submetidos a um curso de capacitação e constituíram o grupo experimental. Os dados foram coletados por meio de um questionário de conhecimentos e uma escala de atitudes. As atitudes dos participantes de ambos os grupos foram positivas. Com relação aos conhecimentos, não se observaram diferenças significativas entre os grupos. Os maiores preditores de atitudes positivas foram possuir preparo para atuar com dependentes químicos $(\mathrm{OR}=2,18)$, ter recebido maior carga horária durante a graduação sobre a temática álcool e outras drogas $(\mathrm{OR}=1,70)$ e ter realizado pós-graduação $(\mathrm{OR}=2,59)$. Concluiu-se que a intervenção educativa exerceu impacto positivo nas atitudes dos enfermeiros frente ao alcoolista, ao trabalho e às relações interpessoais com tal clientela.

\section{DESCRITORES}

Educação em enfermagem

Alcoolismo

Conhecimentos, atitudes e prática em saúde Enfermagem em saúde pública

\section{RESUMEN}

Estudio exploratorio cuasi-experimental que tuvo como objetivo verificar el impacto de una intervención educativa sobre los conocimientos y las actitudes de las enfermeras frente al consumo de alcohol y problemas asociados. La muestra incluyó a 185 enfermeras, divididas en dos grupos. De los cuales, 84 se sometieron a un curso de capacitación y formaron el grupo experimental. Los datos fueron recolectados a través de un cuestionario de conocimientos y una escala de actitudes. Las actitudes de los participantes de ambos grupos fueron positivas. En lo que respecta al conocimiento, no hubo diferencias significativas entre los dos grupos. Los principales predictores de las actitudes positivas fueron estar preparados para actuar con dependientes químicos (OR $=2,18$ ), haber recibido mayor carga horaria en el pregrado sobre la temática de alcohol y otras drogas $(\mathrm{OR}=1,70)$ y haber realizado post-grado $(\mathrm{OR}=2,59)$. Se concluyó que la intervención educativa ejerció impacto positivo en las actitudes de las enfermeras frente a los alcohólicos, al trabajo y a las relaciones interpersonales con dicha clientela.

\section{DESCRIPTORES \\ Educación en enfermería Alcoholismo \\ Conocimientos, actitudes y práctica en salud} Enfermería en salud pública

\footnotetext{
* Extracted from the master's thesis "Atitudes e conhecimentos de enfermeiros frente ao álcool, alcoolismo e alcoolista: Estudo comparativo entre dois grupos", School of Nursing, Universidade de São Paulo, 2010. ${ }^{1}$ Master's in Health Sciences. Doctoral student in the Graduate Program in Nursing, School of Nursing, Universidade de São Paulo. São Paulo, SP, Brazil. janainasoares@usp.br 2 Professor. Doctorate. Department of Maternal-Child Nursing and Psychiatry, School of Nursing, Universidade de São Paulo. São Paulo, SP, Brazil. vargas@usp.br ${ }^{3}$ Professor. Doctorate. Department of Psychobiology,
} Universidade Federal de São Paulo. Coordinator of the SUPERA course. São Paulo, SP, Brazil. mlosformigoni@unifesp.br 


\section{INTRODUCTION}

According to the World Health Organization (WHO) (1), about $10 \%$ of the population in urban centers around the world abuses some psychoactive substance abuse and this problem has reached individuals around the world, regardless of gender, age and social level.

International estimates and the Ministry of Health ${ }^{(2)}$ indicate that between $6-8 \%$ of the population of Brazil about 16 million people - need regular care for disorders related to the harmful use of alcohol and other drugs. The last national survey about psychoactive substance use showed that about $12 \%$ of Brazilians met the criteria for alcohol dependence and that at least $74 \%$ had consumed alcohol at least once in life ${ }^{(3)}$.

According to recent surveys, the majority of the diagnoses of alcohol dependence is confirmed among people in the age range of 40-49 years, which means that the Brazilians most affected by problematic alcohol consumption belong to the economically active portion of the Brazilian labor market, which has a great impact on the economy of the country. The value of the social costs related of this problem in the country reaches more than four billion dollars per year ${ }^{(4)}$.

The social and health costs generated by the problems associated with alcohol use is consistent with research findings that show that people with alcohol dependence occupy a significant number of hospital beds for medical and surgical clinics of general hospitals, for the treatment of physical illnesses ${ }^{(5)}$. It is also common that this clientele receives care services in primary health care $^{(6)}$.

This phenomenon has led to increased contact of the nurse with these people who, until the beginning of the last decade were predominantly treated in services of secondary and tertiary care, usually when the problem was already in advanced stages ${ }^{(2)}$. This fact limited the performance of this professional in the hospital area, since, in most cases, the focus of these services was on physical complications resulting from alcohol dependence and not in addressing the problem itself.

The increase and the magnitude of the problems related to alcohol abuse led WHO to recognize alcoholism as a serious disease that should be treated as a public health problem $^{(2)}$. However, if on one hand the increased demand on health services is clear for people with problems related to alcohol, and alcoholism has been considered a public health problem - factors that led to proposals for various methods for coping ${ }^{(5-6)}$, on the other hand it has been well documented in the literature that nurses have negative attitudes ${ }^{(6-7)}$, stigmatizing ${ }^{(8-9)}$ and grounded in a moral model of etiological explanation of the problem ${ }^{(8,10)}$. This phenomenon deserves attention, since there is evidence ${ }^{(6-10)}$ that negative attitudes of nurses towards people who abuse alcohol may impair the quality of care provided.

Attitudes can be defined as relatively stable affective dispositions that influence responses directed to a particular target or object, positively or negatively, culturally learned and organized through experience ${ }^{(11)}$. The majority of the research on the attitudes of nurses to issues related to alcohol was conducted in the United States ${ }^{(12)}$. Since the end of the last decade, however, Brazil has occupied the second position in this area of research.

In general, international studies have compared the attitudes of nurses with other professionals, evidenced that nurses have recognized their effectiveness in dealing with alcohol users, as well as a greater ability to identify problems related to the use and abuse of alcohol. In addition, nurses who received training for care for alcohol users had more positive attitudes towards the problem that those who called themselves unprepared ${ }^{(13)}$.

An assessment of the changing attitudes of nurses regarding prevention related to alcohol, conducted after the introduction of a system of screening and intervention for alcohol problems, found that nurses presented negative attitudes towards patients' response to treatment. A year after the intervention, the authors observed that only $10 \%$ of the respondents reported experience of negative reactions from patients. Over $50 \%$ of nurses found it easy or very easy to approach the patient about alcohol-related problems and more than $75 \%$ of the nurses agreed that the introduction of this intervention did not affect their workload ${ }^{(14)}$.

A study that examined the attitudes and beliefs of nurses in an emergency department about the care of these users showed that nurses had difficulty performing interventions with these patients due to lack of patient motivation. It also showed that awareness of the professional to the problem contributed to more positive attitudes and more appropriate management of these patients ${ }^{(9)}$.

Currently, international research related to attitudes of nurses towards the issues related to the use and abuse of alcohol have focused on the early identification of users $^{(13)}$, the professional skills to cope with the demands of the patient ${ }^{(9)}$, the satisfaction in working with alcohol users $^{(14)}$ and, principally, the education of nurses from training programs ${ }^{(9,13-14)}$. Although the majority of publications conducted in Brazil $^{(7,10)}$ and abroad ${ }^{(10,14)}$ about the subject attributed negative attitudes to education and inadequate knowledge for dealing with the problem; still scarce, especially in Brazilian literature, are studies that have occupied 
with investigating the knowledge of these professionals, and more specifically, the impact of educational interventions on the nurses' attitudes.

Thus, considering that results of recent studies ${ }^{(15-16)}$ that have evidenced that educational interventions strongly influence a change in attitudes of nurses regarding the problems related to the use and abuse of alcohol, and that in Brazil these studies are scarce, this study aimed to determine the impact of an educational intervention on the attitudes and knowledge of nurses towards alcohol use and associated problems.

\section{METHOD}

This was an exploratory, quasi-experimental study, involving one group of nurses who participated in an educational intervention on alcohol and other drugs, and another that had not been exposed to this intervention. To compare and verify the impact of the educational intervention on the attitudes and knowledge of the participants, a quasi-experimental nonequivalent control group post-test was used ${ }^{(17)}$, since participants were not subjected to a pre-test. This design is characterized by the choice of a comparison group (control group) and a experimental group not equivalent to the control group, which was subjected to the application of the same instrument of evaluation. In the case of this study, both groups responded to the Scale of Attitudes Towards Alcohol, Alcoholism and Alcoholics (SATAAA) and the knowledge questionnaire concerning the independent variables (attitudes and knowledge).

A total of 280 nurses were invited to participate of the study, of which 140 of a university general hospital were allocated to the control group (CG). The other 140 were obtained from primary care services and other health services and had participated in an educational intervention (training course for Distance Education with a workload of 120 hours). These latter were allocated to the experimental group (EG).

Data were collected in the period from January to March of 2010. The CG participants were invited to participate in the study at their workplaces, while the EG subjects received the invitation in their email addresses, provided when they enrolled in the online training course.

\section{Research instrument}

For the measurement of attitudes of the professionals the "Scale of Attitudes Towards Alcohol, Alcoholism and Alcoholics" (SATAAA) was used; an instrument used in several studies, with proven reliability ${ }^{(18)}$. A Likert-type scale, composed of 80 items, with response alternatives ranging from: 1 - totally disagree, 2 - disagree in part, 3 I'm in doubt, 4 - partly agree, 5- totally agree. It measured the principal groups of attitudes: F1: The alcoholic: work and interpersonal relationships; F2: Etiology; F3: Disease;
F4: The repercussions resulting from the use/abuse of alcohol; and, F5: Alcoholic beverage.

A questionnaire that had been used in a previous study and that was adapted by the authors for use among nurses ${ }^{(19)}$ was applied for assessment of knowledge. The questionnaire was composed of four multiple-choice questions and eight statements that were to be considered as true or false. These addressed the following issues: (i) diagnosis of harmful use, dependence and tolerance, (ii) low risk pattern of use, (iii) complications commonly associated with alcohol use (intoxication, abstinence syndrome and alcoholic hallucinosis), (iv) motivational stages for change of behavior of psychoactive substance users, and (v) principles of brief intervention.

\section{Intervention}

The intervention was a distance learning course offered for free by the federal government to prepare health professionals from all over Brazil. Prepared by professionals throughout the country, with extensive experience in the areas of drug policy, prevention of abuse or treatment of alcohol or other drug dependence, its objective was to update healthcare professionals about basic knowledge for the care for users of psychoactive substances, in order to improve care for these patients. It had a duration of four months, a workload of 120 hours, and addressed issues such as: referral of people with problems related to the use of alcohol and other drugs, brief intervention, social rehabilitation and tracking users with problems of the use and abuse of alcohol and other drugs ${ }^{(20)}$.

\section{Data analysis}

Data were analyzed using the Statistical Package for the Social Sciences, version 17.0 (SPSS). The analysis was divided into two stages: a descriptive analysis of the sociodemographic information of the study population, and analysis of data obtained from the questionnaire of knowledge and the SATAAA.

We sought to verify the relationship between attitudes and knowledge, and to compare the results between the two groups (CG and EG) in the SATAAA. Thus, descriptive statistics resulting from the exploratory data analysis were performed, presenting the frequency, percentage and mean of the study variables. Parametric and non-parametric tests were used for comparison between groups, according to the socioeconomic, demographic, and the level of knowledge and attitudes variables.

For the assessment of the scale, 1 and 2 points were assigned to the categories of unfavorable responses to the question posed; 4 and 5 points to the favorable categories, and 3 to the intermediate levels of response. Thus, the mean of the elevated score was considered indicative of positive attitudes and the mean low score,
Knowledge and attitudes of nurses towards alcohol and related problems: the impact of an educational intervention* Soares J, Vargas D, Formigoni MLOS 
of negative attitudes.

With regard to the data analysis resulting from application of the SATAAA, the scores of the factors were calculated according to the responses of the participants in each of the items, which could vary from 1 to 5. And the overall score, that is, the attitude towards the alcoholic, could range from 5-25.

In the analysis of knowledge, each question correctly answered obtained the value of 1 , and every question that was left blank or incorrectly answered, received a 0 value. The knowledge score was obtained by summing the scores for each question, ranging from 0 to 12 .

To verify the relationship between attitudes and knowledge of the participants, a logistic regression was conducted, seeking to encounter variables that could differentiate individuals regarding their attitudes. Given that to use this statistical model, the response variable must be binary, participants were categorized into two groups (one group with positive attitudes and one with negative attitudes) according to the overall score observed on the SATAAA. Those who received a mean overall score $\leq 15$ were categorized in the group of negative attitude, while nurses with a mean overall score $\geq 16$ were categorized in the group of positive attitudes. This cut-off point was established according to the following reasoning: since they are five factors in the SATAAA, the sum of the scores of an individual who was positioned neutrally: (3 - I'm in doubt), in all items would total 15, by multiplying the average score (3) with the number of factors ${ }^{(5)}$, the resulting total score would equal 15 (3 $x 5=15)$. Thus, scores that obtained 1 point above this average were indicative of positive attitudes, and those with 1 point below, of negative attitudes.

This cut-off point was established, and univariate analysis was performed, in order to verify the influence of the variables on the attitudes of nurses towards alcohol, alcoholism and the alcoholic. The analysis model included the sociodemographic variables (gender, age, marital status, professional experience with patients with problems related to alcohol, workload, graduate education), the preparation (to deal with dependent patients), length of employment, type of postgraduate education (specialization, masters or doctorate) and the group, in order to identify the association between each of the variables.

The variables that demonstrated significant association in the univariate logistic regression were included in the multivariate model, the level of significance adopted was $5 \%(p<0.05)$, and the statistics with a $p$ $<0.05$ were considered significant. The analysis showed statistically significant variables: workload, having completed graduate education, and having received preparation for work with those who were chemically dependent. The variables that demonstrated statistical association in the univariate regression were introduced in the multiple regression model, maintaining statistical significance.

\section{Ethical aspects}

The study protocol was approved by the Committee on Ethics in Human Beings of the University Hospital of the University of São Paulo, under protocol number $946 / 09$, and all participants signed the terms of free and informed consent. These procedures aimed to ensure respect for the subjects who participated in the survey, whose development followed ethical standards.

\section{RESULTS}

The study sample was composed of 185 subjects (66\%) who returned completed data collection instruments; 84 (45\%) belonged to the EG and 101 (55\%) to the CG. According to sociodemographic characteristics, the groups showed no significant differences and were similar in the majority of the variables (Table 1 ).

\section{Attitudes and knowledge}

Table 1 - Distribution of the variables included in the study according to each of the groups involved, Experimental Group (EG) and Control Group (CG) - São Paulo, SP, 2013

\begin{tabular}{|c|c|c|c|c|}
\hline \multirow[t]{2}{*}{ Variables } & \multicolumn{2}{|c|}{$\begin{array}{l}\text { Control } \\
(\mathrm{n}=101)\end{array}$} & \multicolumn{2}{|c|}{$\begin{array}{c}\text { Experimental } \\
(\mathrm{n}=\mathbf{8 4})\end{array}$} \\
\hline & $\mathbf{N}$ & $\%$ & $\mathbf{N}$ & $\%$ \\
\hline \multicolumn{5}{|l|}{ Age } \\
\hline 20 - 26 years & 7 & 6,9 & 26 & 30,9 \\
\hline $27-45$ years & 66 & 65,4 & 50 & 59,6 \\
\hline$>45$ years & 28 & 27,7 & 8 & 9,5 \\
\hline \multicolumn{5}{|l|}{ Sex } \\
\hline Female & 91 & 90,1 & 73 & 86,9 \\
\hline Male & 10 & 9,9 & 11 & 13,1 \\
\hline \multicolumn{5}{|l|}{ Marital status } \\
\hline Married & 53 & 52,5 & 39 & 46,4 \\
\hline Single & 40 & 39,6 & 37 & 44 \\
\hline Other & 8 & 7,9 & 8 & 9,6 \\
\hline \multicolumn{5}{|l|}{ Time profession } \\
\hline$<8$ years & 41 & 40,6 & 56 & 66,7 \\
\hline $9-17$ years & 19 & 18,8 & 18 & 21,4 \\
\hline$>17$ years & 41 & 40,6 & 10 & 11,9 \\
\hline \multicolumn{5}{|c|}{$\begin{array}{l}\text { Professional experience } \\
\text { with patients with problems } \\
\text { related to alcohol }\end{array}$} \\
\hline Yes & 49 & 48,5 & 45 & 53,6 \\
\hline No & 52 & 51,5 & 39 & 46,4 \\
\hline \multicolumn{5}{|l|}{ Educational institution } \\
\hline Educational institution & 40 & 39,6 & 28 & 33,4 \\
\hline Privada & 61 & 60,4 & 56 & 66,6 \\
\hline \multicolumn{5}{|l|}{ Postgraduate } \\
\hline Yes & 89 & 88,1 & 63 & 75 \\
\hline No & 12 & 11,9 & 21 & 25 \\
\hline
\end{tabular}

Continue... 
...Continuation

\begin{tabular}{lcccc}
\hline \multirow{2}{*}{ Variables } & \multicolumn{2}{c}{$\begin{array}{c}\text { Control } \\
(\mathbf{n}=\mathbf{1 0 1})\end{array}$} & \multicolumn{2}{c}{$\begin{array}{c}\text { Experimental } \\
(\mathbf{n}=\mathbf{8 4})\end{array}$} \\
\cline { 2 - 5 } & $\mathbf{N}$ & $\mathbf{\%}$ & $\mathbf{N}$ & $\mathbf{\%}$ \\
\hline Postgraduate Type & & & & \\
Specialization & 75 & 74,2 & 76 & 90,5 \\
Master's degree & 19 & 18,8 & 7 & 8,3 \\
Doctorate & 7 & 7 & 1 & 1,2 \\
\hline
\end{tabular}

Preparation in chemical

dependency

\begin{tabular}{lllll} 
Yes & 39 & 38,6 & 39 & 46,4 \\
No & 62 & 61,4 & 45 & 53,6 \\
\hline Classroom hours & & & & \\
$\quad<10$ hours & 78 & 77,2 & 55 & 65,5 \\
$\quad$ Others & 23 & 22,8 & 29 & 34,5 \\
\hline
\end{tabular}

Considering the mean scores obtained on the SATA$A A$ in its entirety, it was observed that the total mean score was 14.2 in the CG and 14.4 in the EG (Figure 1). When analyzing the means in each of the factors that composed the instrument, it was found that in both groups the highest scores were found in the factors: 1. Attitudes toward the alcoholic: work and interpersonal relationships; 2 . Attitudes toward the etiology for alcoholism; and, 5. Attitudes related to alcoholic beverages. It was evident even in Factor 1 that the EG had a higher mean score (3.9 vs. 3.3 of the $C G$ ).

The lowest scores obtained by the two groups were observed in Factor 3: Attitudes towards the disease, and Factor 4: Attitudes toward the repercussions of the problem, whose means were in the zone of negativity, meaning scores $<2.5$. In the knowledge questionnaire, it was observed that there was no significant difference in mean scores, since in both groups the mean score (50\%) was similar (Figure 1 ).

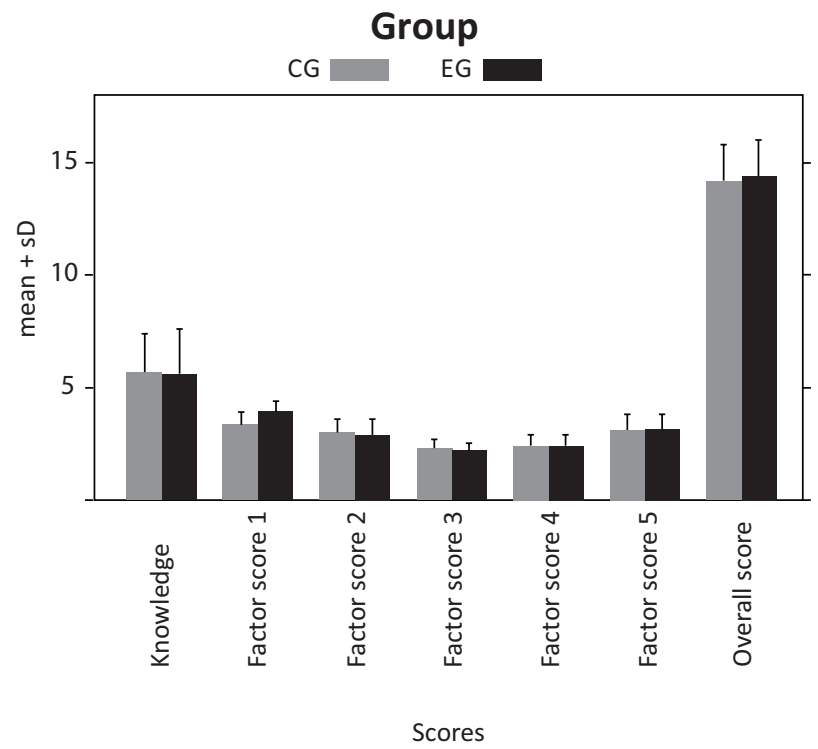

Figure 1 - Distribution of mean scores of attitudes on the SATAAA and each factor score in the knowledge questionnaire, observed in the control group (CG) and experimental group (EG).
In the multiple logistic regression, the statistically significant variables in the univariate analysis (receiving preparation to act with dependents during education in nursing; amount of workload received; having completed graduate education) were included in the model, noting that these variables remained positively associated with positive attitudes towards alcohol, alcoholism and the alcoholic, and can be characterized as the best predictors of this association (Table 2).

Table 2 - Logistic regression of the total sample, analysis of the relationship between attitudes towards alcohol, alcoholism and the alcoholic, with the significant variables of the study - São Paulo, SP, 2013

\begin{tabular}{|c|c|c|c|c|c|}
\hline & Estimative & OR & \multicolumn{2}{|c|}{ IC95\% } & p-value \\
\hline $\begin{array}{l}\text { Work hours dispensed } \\
\text { about the topic }\end{array}$ & -0.534 & 1,705 & 0,84 & 2,58 & $0.03 *$ \\
\hline Graduate education & -0.953 & 2,593 & 1,26 & 3,92 & $0.02 *$ \\
\hline $\begin{array}{l}\text { Received preparation } \\
\text { on the subject during } \\
\text { undergraduate nursing } \\
\text { education }\end{array}$ & -0.781 & 2,183 & 1,91 & 2,46 & $0.05^{*}$ \\
\hline
\end{tabular}

*Values of the significant variables in the study. Note: $(n=185)$

\section{DISCUSSION}

When the profile of groups of participants was evaluated, it was found that in both there was a predominance of females. In addition, the EG was predominantly younger in age and length of employment. The members of the CG, despite the longer time in the profession, had less professional experience with alcoholics, even in the face of the indicators from the literature that there is a growing demand of patients with problems due to the use/abuse of alcohol in hospital institutionss, as well as in health care in general ${ }^{(5-6)}$.

According to the literature, professionals in general health services have difficulty with identifying the problem with the patients ${ }^{(5-6,13)}$. These difficulties arise from the limited ability of professionals to identify and diagnose early cases of problematic alcohol use, given the lack of knowledge and practical skills for approaching the problem ${ }^{(13,21)}$.

Less than $50 \%$ of the total participants in the research reported receiving some kind of preparation about alcohol and other drugs during undergraduate courses. These results are consistent with previous studies ${ }^{(14,21)}$ that showed that this issue has not been provided in an adequate manner in the Brazilian nursing curricula(21). During their education, the nurses received a limited number of classroom hours on the subject ${ }^{(21-22)}$.

However, in this study it was observed that, among those participants who reported having received such preparation during their undergraduate nursing course, the majority reported receiving up to ten hours of instruction or training, classroom hours greater than those reported in previous studies, which ranged from two to eitgh hours ${ }^{(21-22)}$. 
In the attitudes question, it was observed that nurses in both groups tended to present neutral to slightly positive attitudes, a result consistent with previous research conducted in the country ${ }^{(10,17)}$. Analyzing each of the factors that comprise the SATAAA, it was observed that the EG tended to have more positive attitudes towards the alcoholic (Factor 1), different than the attitudes towards alcoholism that, in both groups, were negative. This amounts to saying that the alcoholic person is more accepted by nurses that his illness, facing that a significant portion of the nurses presented negative and moralistic attitudes $^{(7-8)}$. But then again, studies have shown that nurses are favorable to treatment for alcoholism, however present negative attitudes towards satisfaction in working with this population ${ }^{(8,13)}$.

Assessing the relationship between attitudes and knowledge, it was observed that there were no differences in the level of knowledge, since in both groups the mean knowledge and general attitude were proximate. In contrast to this result, one study ${ }^{(10)}$ showed that preparation and knowledge were directly related to positive attitudes toward the alcoholic patient, suggesting that the level of utilization of knowledge must be greater than $50 \%$ so that the education offered has impact on the attitudes of nurses to confront the problems related to the use and abuse of alcohol.

A statistically significant association between the more positive attitudes and the variables, having received preparation to act with dependents during undergraduate nursing education; more classroom time received about the theme, and completed graduate education was found when the association between sociodemographic and educational were investigated, which shows that these were the strongest predictors of this association. The result indicated that nurses with a higher level of education (graduate), who had access to knowledge on the subject during undergraduate education (preparation in chemical dependency) and longer classroom hours tended to have more positive attitudes to alcohol, alcoholism and the alcoholic. This result is supported by the literature, which identified the positive impact of training and education on the attitudes of professionals about issues relating to alcohol and other drug use $\mathrm{e}^{(15)}$ and that the preparation and knowledge were directly related to positive attitudes ${ }^{(10)}$.

In this study, the objective was to evaluate the impact of a training course about alcohol and other drugs on the attitudes of nursing professionals, especially by the fact that, according to the literature, continuing education has shown satisfactory results in improving the attitude of these professionals $^{(15)}$. However, with the exception of Factor 1, in which the participants of the EG had more positive attitudes than those in the CG, it was observed that both groups showed similar scores on general attitude and knowledge. It was hoped that the EG would exhibit greater knowledge about the theme than the $\mathrm{CG}$, as this group received specific training in alcohol and other drugs.
However, it was not possible to say that the training course did not influence these variables, since evidence exists in the literature ${ }^{(16)}$ that the improvement of attitudes may be related to practice time after the professional has received such training, as well as the increase of knowledge that derives from the acquired skills in the interaction of nurses trained with the patient in the course of their practice ${ }^{(15)}$. This result points to the need to conduct follow-up studies with this population of trained nurses, which can support the elucidation of this question.

\section{Limitations of the study}

The major limitation of this study lies in the fact that the EG was not subjected to a pretest, which justifies the presented design. Moreover, the choice of the institution for recruiting the CG may not have been adequate, since it has a large number of professionals with master's and doctoral degrees, which can includence the results, mainly because the preparation is touted as an explanatory variable to more positive attitudes. The demographic heterogeneity between CG and EG can also be considered a limitation, represented by differences in age range, length of service and level of education.

It is possible that the instruments used were not sensitive enough to distinguish the difference between the attitudes and knowledge of the two groups, and the questionnaire may not have been comprehensive enough to identify knowledge that others have not addressed.

Despite these issues that limit the generalizability of the results, this research brings advances for knowledge in the area, since it is one of the few national studies seeking to verify the impact of an educational intervention on attitudes and knowledge of nurses towards alcohol use and problems associated with it. Furthermore, it subsidizes knowledge, identifying ways to further investigations in the area.

Ideally, new experiments will be performed (pre-and post-test) involving other populations, seeking to identify the influence of courses and training on attitudes and knowledge of these professionals, which - ultimately - may help guide new strategies or improve those that already exist.

\section{CONCLUSION}

Participants of the EG who received the training course on alcohol and other drugs had similar general attitude scores to those of the CG, but the EG had higher scores on factor 1 , suggesting that the educational intervention exerted impact on the attitudes of nurses towards the work and relationship with these patients. Regarding knowledge, there were no significant differences between the experimental and control groups, since the means of knowledge and general attitude were close in both groups. 
Having preparation for working with addicts, having received greater classroom hours during undergraduate education about the issue of alcohol and other drugs, and having a graduate degree, regardless of the area, were the best predictors for positive attitudes in our sample, independent of the group (experimental or control).

Considering the need for identification and evaluation of new methods that foster the acquisition of knowledge and changing attitudes of nurses towards issues related to alcohol and other drugs, it is important to investigate the impact of such educational strategies on the professionals' attitudes. Considering that the course

\section{REFERENCES}

1. Organização Mundial da Saúde (OMS). Relatório Sobre a Saúde do Mundo. Saúde mental: nova concepção, nova esperança. Genebra; 2001.

2. Brasil. Ministério da Saúde; Secretaria de Atenção à Saúde. A Política do Ministério da Saúde para Atenção Integral a Usuários de Álcool e outras Drogas [Internet]. Brasília; 2004 [citado 2012 ago. 14]. Disponível em: http://portal. saude.gov.br/portal/arquivos/pdf/politica_de_ad.pdf

3. Carlini EA, supervisão. II Levantamento Domiciliar sobre Uso de Drogas Psicotrópicas no Brasil: estudo envolvendo as 108 maiores cidades do país, 2005. Brasília: CEBRID/ UNIFESP/SENAD; 2006.

4. Gallassi AD, Alvarenga PG, Andrade AG, Couttolenc BF. Custos dos problemas causados pelo abuso do álcool. Rev Psiquiatr Clín. 2008;35 Supl.1:25-30.

5. Sousa FSP, Oliveira EN. Caracterização das internações de dependentes químicos em Unidade de Internação Psiquiátrica do Hospital Geral. Ciênc Saúde Coletiva [Internet]. 2010 [citado 2012 ago. 14];15(3):671-7. Disponível em: http://www.scielo.br/pdf/csc/v15n3/v15n3a09.pdf

6. Vargas D, Araújo E. Prevalência de dependência alcoólica em serviços de Atenção Primária a Saúde de Bebedouro (SP) - Brasil. Cad Saúde Pública. 2009;25(8):1711-20.

7. Vargas D, Luís MAV. Alcohol, alcoholism and alcohol addicts: conceptions and attitudes of nurses from district basic health centers. Rev Latino Am Enferm. 2008;16(n. spe):543-50.

8. Ronzani TM, Furtado EF. Estigma social sobre o uso de álcool. J Bras Psiquiatr. 2010;59(4):326-32.

9. Indig D, Copeland J, Conigrave KM, Rotenko I. Attitudes and beliefs of emergency department staff regarding alcoholrelated presentations. Int Emerg Nurs. 2009;17(1):23-30. is multidisciplinary, it is suggested that studies involving other professions are conducted.

These results suggest that the preparation and education on issues related to alcohol and alcoholism given during professional education positively influenced the attitudes toward this phenomenon, which reinforced the recommendations of the specialists that courses should be included specifically related to the area of alcohol and other drugs in nursing curricula and other professional categories, ensuring sufficient theoretical and practical workload for adequate education of health professionals.

10. Amaral-Sabadini MB, Saitz R, Souza-Formigoni MLOS. Do attitudes about unhealthy alcohol and other drug (AOD) use impact primary care professionals' readiness to implement AOD-related preventive care? Drug Alcohol Rev. 2010;29(6):655-61.

11. Krech D, Crutchfield RS, Ballachey EL. O indivíduo na sociedade: um manual de psicologia social. São Paulo: EDUSP; 1969.

12. Vargas D, Soares J. Atitudes de enfermeiros frente ao alcoolismo: revisão da literatura. Cogitare Enferm. 2011;16(2):340-7.

13. Tsai YF, Tsai MC, Lin YP, Weng CE, Chou YL, Chen CY. An alcohol training program improves Chinese nurses' knowledge, self-efficacy, and practice: a randomized controlled trial. Alcohol Clin Exp Res. 2011;35(5):976-83.

14. Bendtsen P, Holmqvist M, Johansson K. Implementation of computerized alcohol screening and advice in an emergency department--a nursing staff perspective. Accid Emerg Nurs. 2007;15(1):3-9.

15. Munro A, Watson HE, McFadyen A. Assessing the impact of training on mental health nurses' therapeutic attitudes and knowledge about co-morbidity: a randomized controlled trial. Int J Nurs Stud. 2007;44(8):1430-8.

16. Ford R, Bammer G, Becker N. Improving nurses' therapeutic attitude to patients who use illicit drugs: workplace drug and alcohol education is not enough. Int J Nurs Pract. 2009;15(2):112-8.

17. Vargas D. Reduced version of the scale of attitudes towards alcohol, alcoholism, and alcoholics: primary results. Rev Esc Enferm USP [Internet]. 2011 [cited 2012 Aug 14];45(4):91825. Available from: http://www.scielo.br/pdf/reeusp/ v45n4/en_v45n4a18.pdf

18. Campbell DT, Stanley JC. Delineamentos de experimentais e quase-experimentais de pesquisa. São Paulo: EPU; 1979. 
19. Silva CJ. Impacto de um curso em diagnóstico e tratamento do uso nocivo e dependência do álcool sobre a atitude e conhecimento de profissionais da Rede de Atenção Primária à Saúde [tese doutorado]. São Paulo: Escola Paulista de Medicina, Universidade Federal de São Paulo; 2005.

20. Brasil. Ministério da Justiça; Secretaria Nacional de Políticas sobre Drogas; Universidade Federal de São Paulo. Curso SUPERA [Internet]. São Paulo; 2012 [citado 2012 ago. 14]. Disponível em: http://www.supera.senad.gov.br/
21. Lopes GT, Pessanha HL. Concepções de professores de enfermagem sobre drogas. Esc Anna Nery Rev Enferm. 2008;12(3):465-72.

22. Vargas D. Nursing students' attitudes towards alcohol, alcoholism and alcoholics: a study of a Brazilian sample. J Nurs Educ Pract [Internet]. 2012 [cited 2012 Aug 10];2(1). Available from: http://www.sciedu.ca/journal/index.php/jnep/ article/view/296/319 